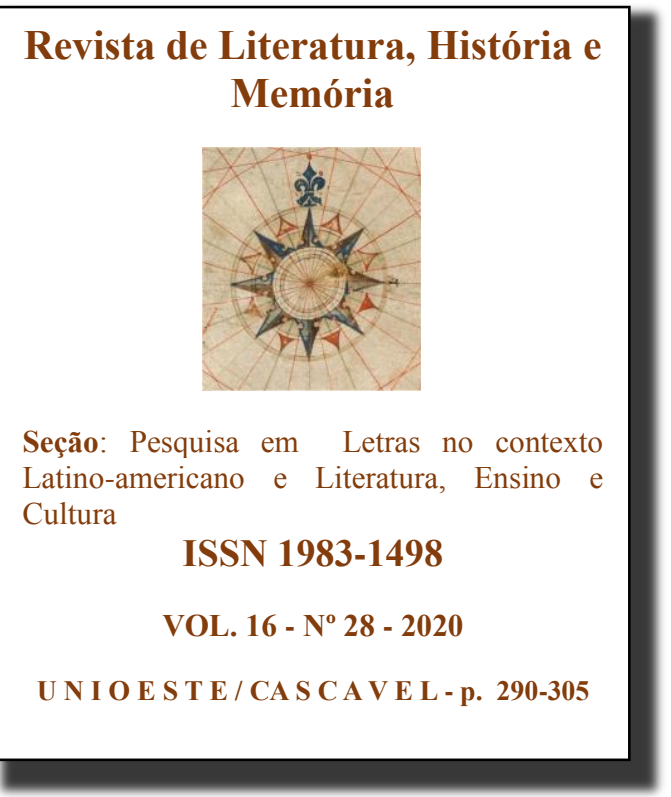

\title{
A RELAÇÃO DO INDIVÍDUO COM O MEIO ATRAVÉS DA LINGUAGEM, EM O PÊNDULO DO RELÓGIO
}

\author{
The interaction of the individual with the enviroment \\ through language in The pendulum of the clock
}

Viviane Aparecida Pandolfo Debortolli ${ }^{1}$

RESUMO: A proposta deste artigo é analisar a novela $O$ Pêndulo do Relógio, do escritor brasileiro Charles Kiefer, levando em consideração a perspectiva de que a falta de domínio da linguagem pode levar o sujeito a não compreender seu mundo circundante, de forma que ele se torna uma vítima desta condição, enquanto participante de uma sociedade que ele não entende. Os pressupostos teóricos utilizados nesta análise se baseiam principalmente nos estudos de Michael Foucault, quando elenca questões como conhecimento, poder e linguagem. A partir de tais pressupostos, evidencia-se a maneira problemática como o protagonista se relaciona com o meio, e o efeito nocivo que isso tem em sua vida.

PALAVRAS-CHAVE: Conhecimento; Linguagem; Narrativa; Literatura.

ABSTRACT: The purpose of this article is to analyze the novel O Pêndulo do Relógio, by Brazilian writer Charles Kiefer, to take into account the perspective that the lack of mastery of language can lead the individual to not understand his surrounding world, so that he becomes a victim of this condition, while participating in a society he doesn't understand. The theoretical assumptions used in this analysis are based mainly on the studies of Michael Foucault, when he lists issues such as knowledge, power and language. Based on these assumptions, it is evident the problematic way in which the protagonist relates to the environment, and the harmful effect that this has on his life.

KEYWORDS: Knowledge; Language; Narrative; Literature.

\section{INTRODUÇÃO}

Os estudos contemporâneos de Teoria da Literatura abarcam diversas formas de pensar o texto literário, seja na sua estrutura, no contexto de produção, em como ele é recebido pelo público leitor, entre outras questões. Estudos de áreas como a filosofia e a psicologia vêm sendo adotados pela crítica literária para dar conta de questões antes negligenciadas. Isso ocorreu principalmente com o pensamento pós-estruturalista, termo que

é usado para referir uma ampla gama de discursos teóricos nos quais há uma crítica das noções de conhecimento objetivo e de um sujeito capaz de se conhecer. Desse modo, os feminismos, as teorias psicanalíticas, os

\footnotetext{
${ }^{1}$ Mestre em Letras pela Universidade Federal de Santa Maria (UFSM). Professora efetiva da rede pública do estado do Rio Grande do Sul.
} 
marxismos, e historicismos contemporâneos todos participam do pósestruturalismo (CULLER, 1999, p. 122).

Se o estruturalismo vinha pensando o texto literário como uma organização binária, em que o sentido de algo se dava em relação aos seus opostos, o pós-estruturalismo pautou-se na possibilidade de ver um mesmo elemento por contextos diferentes; certezas foram postas em xeque pois houve, a partir de então, a noção de que conceitos como a verdade em oposição à falsidade, por exemplo, poderiam ser mais subjetivos do que eram considerados até então. Nesse quadro, estratégias usadas por críticos pós-estruturalistas passaram a levar em conta a desconstrução, depois de terem compreendido que

as oposições binárias, com as quais o estruturalismo clássico gosta de trabalhar, representam uma maneira de ver típica das ideologias. Estas tendem a traçar fronteiras rígidas entre o que é aceitável e o que não é, entre o eu e o não-eu, a verdade e a falsidade, o sentido e o absurdo, a razão e a loucura, o central e o marginal, a superfície e a profundidade (EAGLETON, 2006, p. 200).

Dessa maneira, qualquer distinção absoluta é rejeitada pelo pós-estruturalismo, "estilo de pensamento que abarca as operações desconstrutivas de Derrida, da obra do historiador francês Michel Foucault, dos escritos do psicanalista francês Jacques Lacan e da filósofa e crítica feminista Julia Kristeva (EAGLETON, 2006, p. 202)”. Considerando isso, a proposta desta análise baseia-se nos pressupostos pós-estruturalistas, especialmente na obra de Foucault, particularmente no que concerne à linguagem. A tentativa que se fará adiante é de evidenciar a problemática relação que o protagonista de $O$ Pêndulo do Relógio estabelece com o meio em que vive através da linguagem; parte-se do pressuposto de que o restrito domínio comunicativo impede que o personagem seja capaz de se proteger em meio a um sistema que ele desconhece; o horizonte de expectativa do personagem difere dos preceitos do banco e da cooperativa a que está ligado, e a dificuldade de comunicação entre as empresas e o personagem culmina na completa derrocada do protagonista.

\section{A RELAÇÃO DO PERSONAGEM COM A LINGUAGEM}

A escolha da novela de Kiefer, publicada em 1984, deu-se em virtude de que os personagens, especialmente o protagonista, apresentam características realistas e é possível fazer uma analogia entre a ficção e a realidade que serviu de contexto de produção, pois ela se situa em tempo e espaço definidos. 
Além da precária linguagem comunicativa e social, há de se considerar dois elementos da tecnologia presentes na humilde casa do protagonista, com os quais ele parece manter um contato próximo, visto que mantém com eles uma espécie de comunicação: o relógio de pêndulo e o rádio. Ambos funcionam como elemento de opressão ao protagonista, que não dispõe de muitos recursos para entender a lógica dos diferentes sistemas que o cercam.

O próprio objeto relógio carrega em si o peso da marcação visual e auditiva da passagem d tempo. A tomada consciência sobre o esgotamento e a má utilização do tempo, tão presentes na narrativa e na vida do protagonista, tem também registros históricos, isso porque, de acordo com Walter Benjamin (1994)

Os calendários não marcam o tempo do mesmo modo que os relógios. Eles são monumentos de uma consciência histórica da qual não parece mais haver na Europa, há cem anos, o mínimo de vestígio. A Revolução de julho registrou ainda um incidente em que essa consciência se manifestou. Terminado o primeiro dia de combate, verificou-se que em vários bairros de Paris, independente uns dos outros e na mesma hora, foram disparados tiros contra os relógios localizados nas torres (BENJAMIN, 1994, p. 230).

O rádio, por sua vez, funciona na narrativa como uma espécie de simulacro de poder, e por isso, de opressão. A utilização do rádio em contextos como os de O Pêndulo do Relógio, em que ele é o principal meio de acesso ao que é externo à propriedade, aliado à importância que ele adquire na casa, até por ter seu uso restrito basicamente à transmissão do noticiário, dão uma ideia do peso que tinha na vida das pessoas aquilo que ele transmitia; é como se o rádio passasse a ter um poder que ele efetivamente não tem, mas que parece ter. Aos olhos e ouvidos de comunidades como as de Pau-d'Arco esse meio de comunicação cria no imaginário das pessoas uma força que não lhe é própria, e a recepção do que é transmitido passa a ter uma força que não teria se fosse transmitida por um outro meio, como uma carta, por exemplo.

O protagonista descobre através do rádio que deveria comparecer ao banco por causa de dívidas; o que era para ser apenas uma informação adquire proporções gigantescas, ele se sente extremamente pressionado e passa a imaginar que todos os vizinhos sabem que ele deve. Aqui se observa o poder do simulacro do rádio, que ocupa um lugar e importância que não lhes são próprios. Ele age na mente do personagem, e o peso que este dá à informação que o rádio transmitiu gera nele um transtorno psicológico que no final o leva ao suicídio. Consoantes com esse argumento estão os postulados de Baudrillard (1981), que trata sobre o assunto ao discorrer a respeito de simulacros e simulações. 
A informação devora os seus próprios conteúdos. Devora a comunicação e o social. (...) Em vez de fazer comunicar, esgota-se na encenação do sentido. Gigantesco processo de simulação que é bem nosso conhecido. (...) A informação é cada vez mais invadida por uma espécie de conteúdo fantasma, de transplantação homeopática, de sonho acordado da comunicação (BAUDRILLARD, 1981, p. 105).

Ou seja, no caso de $O$ Pêndulo do Relógio, é como se o próprio dono do banco tivesse ido falar com Alfredo; só que essa voz que vem do além, da tecnologia é um simulacro do poder, não é o poder, embora gere no personagem uma força opressiva equivalente a do poder. Essa força opressiva está associada à ausência de domínio da linguagem e dos mecanismos dos meios comunicativos que o cercam. A informação transmitida pelo rádio esvaziou-se de ser apenas comunicação e passou a ser o próprio problema do personagem; tão humilhante quanto dever, era saber que outros sabiam disso. E foi o rádio o propagador da notícia que para o protagonista se transformou no vórtice de seu problema.

O caráter social da obra de Kiefer está presente em grande parte de sua escrita e carregam em si questões como a precária linguagem. Diversas características desses enredos permitem fazer uma aproximação entre o texto ficcional e a realidade tomada como base, especialmente porque um dos propósitos da escrita do autor era justamente fazer com que os fatos de seu tempo não se perdessem ao longo da história sem que tivessem sido registrados pela literatura. Tal argumento encontra respaldo no fato que $O$ Pêndulo do Relógio fala sobre a vida de Alfredo Muller, pequeno agricultor que se vê enredado em dívidas contraídas a partir da tentativa frustrada da troca da agricultura de subsistência desenvolvida em sua propriedade pela monocultura da soja, tipo de cultivo em expansão na época, a respeito do qual ele não tinha o mais vago conhecimento técnico sobre a produção nem dispunha de implementos agrícolas suficientes para lograr êxito. O fracasso de suas escolhas chegou ao extremo de ele cometer suicídio por enforcamento, depois de não conseguir postergar o pagamento das dívidas, de não compartilhar com sua família as dificuldades pelas quais todos passavam e de não ser capaz de conviver com a vergonha de ter sua honestidade posta à prova, e especialmente pela possibilidade iminente de ter que entregar suas terras ao banco e ver seus filhos vagarem pelo mundo em busca de qualquer trabalho que lhes garantisse a sobrevivência.

A geografia local equivale à região de Três de Maio (RS), terra natal de Kiefer e que foi transposta ao texto literário como Pau-d'Arco, pequena cidade colonizada principalmente por descendentes de alemãs. O presente da narrativa é o início de agosto de 1980 quando, aos quarenta e oito anos, casado há vinte e sete, pai de quatro filhos, proprietário de uma pequena 
propriedade rural, Alfredo Muller, num sábado chuvoso, tenta preparar comida para sua porca enquanto reflete sobre sua dificuldade financeira.

$\mathrm{Na}$ cooperativa falavam em lei da oferta e procura. Não estava interessado em leis e já não dava tanto crédito ao que os técnicos diziam, tinha sido engambelado diversas vezes. Pra dizer a verdade, andava receoso, desconfiado, disposto a pedir o cancelamento de sua matrícula de associado. Chegara a ir ao escritório da Cooperativa há seis meses atrás.

- Não enquanto não saldar a dívida - disseram-lhe.

Quis saber quanto devia, quase desmaiou. A vista escureceu e o estômago enrolou. Uma babilônia, uma conta astronômica.

- Mas, argumentou - devo só alguns sacos de adubo, calcário, um arado e sementes.

- Esqueceu os juros, a correção monetária?

Tentou calcular quantos sacos de soja teria de entregar, ao preço do dia, para saldar a dívida. Não conseguiu. Sua matemática não alcançava tanto, os números misturaram-se no cérebro (KIEFER, 1994, p. 7-8).

O excerto acima é abundante em elementos que dão conta do que se pretende analisar aqui. O fragmento narra os pensamentos do personagem; ou seja, o personagem ao mesmo tempo pensa e rememora um encontro que tivera com um dos membros da cooperativa, cujo diálogo é reproduzido pelo narrador. Pensamento e linguagem, para Foucault (2007), não são a mesma coisa. O pensamento precisa da linguagem para se manifestar, mas esta não dá conta de representá-lo de forma ampla sem antes passar por uma ordem linear. Nas palavras do autor

$\mathrm{O}$ que distingue a linguagem de todos os outros signos e lhe permite desempenhar na representação um papel decisivo não é tanto o fato de ser individual ou coletiva, natural ou arbitrária. Mas, sim, o fato de que ela analisa a representação segundo uma ordem necessariamente sucessiva: os sons, com efeito, só podem ser articulados um a um; a linguagem não pode representar o pensamento, de imediato, na sua totalidade; precisa dispô-lo parte por parte segundo uma ordem linear (FOUCAULT, 2007, p. 113).

Os pensamentos de Alfredo se dão por meio da linguagem, que segue uma ordem linear de reflexão. A primeira constatação a que ele chega é que na cooperativa falam de algo que ele não sabe bem o que é, a lei da oferta e da procura. Não fica claro quem são as pessoas que falam, porque o sujeito da oração não é determinado, mas subentende-se que seja alguém que domina o assunto, o qual o agricultor desconhece por completo. Ao afirmar que ele não estava interessado em leis, é possível perceber que Alfredo e os chefes da cooperativa mantinham uma relação diferente com um assunto comum, visto que para eles saber dos mecanismos de oferta e procura era fundamental para os negócios. O que o personagem 
sequer supunha, é que ele também deveria ter se interessado em descobrir como isso funcionava, porque ele estava inserido nesse meio e dependia da compreensão dessa lógica para ter êxito em seu negócio, o qual havia começado quinze anos antes, quando deixara de plantar mandioca e batatas, verduras e legumes para cultivar soja.

Outro fator que desencadeou a situação precária na qual se encontrava era o fato de não ter dado crédito aos técnicos, o que sugere a falta de apreço que tinha por conhecimento científico. Os técnicos representam o que seria esse conhecimento, eles poderiam ter a chave que daria acesso a uma produção mais rentável, mas desconfiar das indicações deles equivalia a dizer que o conhecimento prático que ele tinha era suficiente, embora nunca antes havia plantado aquele tipo de cultivar. $\mathrm{O}$ que ele entendia por ser certo não era o mesmo que os técnicos entendiam. A lógica do conhecimento era diferente para cada um.

A expressão que Alfredo usa em seu raciocínio para justificar a si mesmo o motivo pelo qual não dava crédito aos técnicos pode ser reveladora da relação que ele tinha com o meio em que estava inserido, através da linguagem, pois o termo engambelado pode ser associado a enganado, seduzido, e é engando aquele que não consegue discernir os prós e os contras em uma proposta, em uma negociação. Se os técnicos o haviam engambelado, significa que eles dispunham de um discurso persuasivo capaz de levar alguém a fazer o que não deveria. Se os técnicos apenas apresentavam, sugeriam e davam dicas de produção, quem não fora capaz de filtrar as informações e absorver o que fosse melhor para si era ele. A precariedade de sua capacidade de discernimento associada ao provável discurso seguro dos técnicos evidenciam a dificuldade de diálogo pelo qual ele passou, porque uma comunicação eficiente não resultaria em uma engambelação.

O prejuízo oriundo disso era tanto que ele estava disposto a deixar de ser sócio da cooperativa, mas descobriu que só poderia fazer isso depois de quitar suas dívidas. Ou seja, mais uma vez ele fora vítima do desconhecimento das regras que regiam o contexto em que se inserira. $\mathrm{O}$ fracasso comunicativo estaria associado ao fracasso financeiro e o eixo primordial dessa ruína se dava pela sua quase total falta de conhecimento acerca do funcionamento dos bancos, da cooperativa, do cultivo da soja, da lei da oferta e da procura e de tudo o mais que dizia respeito às coisas de seu trabalho. Ao considerar o pressuposto de Foucault de que

conhecimento e linguagem estão estreitamente entrecruzados. Têm na representação mesma origem e mesmo princípio de funcionamento; apoiamse um ao outro, completam-se e se criticam incessantemente (FOUCAULT,2007, p. 120). 
é possível ponderar que a falta de conhecimento do personagem, que determina sua derrota, está intimamente concatenada com sua linguagem frágil que o vulnerabiliza ante suas decisões, que o impede de entender as explicações dos técnicos, dos chefes e afins. Do mesmo modo, pressupõe-se que a limitação de sua linguagem se dá em virtude do seu afastamento do conhecimento. Então, pouco conhecimento prejudica o uso da linguagem e linguagem escassa prejudica o conhecimento. A respeito dessa relação, diz Foucault

Mas a linguagem só é conhecimento de uma forma irrefletida; impõe-se do exterior aos indivíduos que ela guia, quer queiram quer não, em direção a noções concretas ou abstratas, exatas ou pouco fundadas; o conhecimento, em contrapartida, é como uma linguagem de que cada palavra tivesse sido examinada e cada relação verificada (FOUCAULT, 2007, p. 120).

Se a linguagem se expõe do interior ao indivíduo, é pela relação com o meio que ela se define e é definidora. Alfredo não conseguia entender a matemática, a economia, a legislação e o funcionamento bancário. Isso, associado à fragilidade de seus argumentos, compõe o sumo em que o personagem está imerso, num universo em que o poder do discurso do conhecimento está irrigado pela linguagem.

Depois de finalmente conseguir alimentar a porca, o agricultor se protege da garoa no paiol, onde segue refletindo a respeito de sua vida. Rememora então um fato em que a esposa teve que ser internada e reclama que "descontam religiosamente a taxa de cada saco entregue na Cooperativa mas na hora do vivente precisar de médico é tratado como um cachorro (...)(KIEFER, 1994, p.9)", raciocínio que segue com a lembrança da pergunta que fez ao atendente ao sair do hospital, ao questionar a situação enfrentada:

- Para que serve o sindicato?

$\mathrm{O}$ atendente sorriu da ingenuidade de Alfredo e respondeu:

- Pra bonito (KIEFER, 1994, p. 9).

A escolha lexical do narrador ao revelar o julgamento do atendente a respeito do personagem remete ao caráter quase inocente de Alfredo; é na infância que o ser humano ainda não tem consciência da maldade presente na sociedade. A ingenuidade é própria de pessoas que ainda não têm um domínio significativo da linguagem, do conhecimento, do poder, de como funciona o capitalismo, etc. Embora fosse adulto, Alfredo era engambelado com facilidade, era visto como alguém ingênuo, que provavelmente não era capaz de discernir ironias e que possivelmente não tinha uma atitude crítica perante o que ouvia, pois se iludiu facilmente com a ideia de que 
não vale a pena plantar nada além de soja, por isso aproveita quase toda a extensão da propriedade. Alzira brigou quando ele desmanchou a horta atrás do chiqueiro.

- Besteira plantar rabanetes, mulher. Precisamos espaço para a soja. (KIEFER, 1994, p. 10).

A partir da situação em que a família se encontra, fica claro que destruir até mesmo a horta para cultivar soja não foi uma boa ideia, porque a partir de então tiveram que passar a comprar todos os produtos alimentícios, só que até mesmo o crédito no mercadinho a cooperativa havia cancelado em razão da falta de pagamento. Não fica claro quem convenceu o agricultor de que a soja seria a melhor opção, mas o contexto da época possivelmente foi um grande facilitador dessa decisão. Ele, que não conhecia nada de soja, sabia que não valia a pena cultivar outra coisa. Essa sabedoria provavelmente viera das conversas com os vizinhos e fora fruto de sua ingenuidade, por não levar em considerações as intempéries climáticas, por não colocar na conta o grande investimento que teria que fazer com máquinas ou o grande esforço físico que depreenderia de todos para levar a produção adiante, bem como o fato de que se nada disso desse certo eles sequer teriam o que comer, pois não teriam nada plantado com que pudessem matar a fome. O valor das coisas também é discutido por Foucault, quando diz que "toda riqueza nasce da terra; o valor das coisas está ligado às trocas; a moeda vale como a representação das coisas em circulação (FOUCAULT, 2007, p. 276)"'. Talvez se o personagem de $O$ Pêndulo do Relógio tivesse acesso ao conhecimento erudito ele poderia presumir que no período de safra, que era quando ele e todos os outros agricultores dispunham da soja e precisavam pagar as dívidas, o preço do produto caía porque havia bastante oferta, e quando já não tinham mais o preço subia porque diminuía a quantidade de produto no mercado.

O fragmento literário acima revela ainda a falta de diálogo entre o casal, ou, mais ainda, a completa desconsideração do marido em relação à opinião da mulher, aparentemente menos iludida que ele.

$\mathrm{Na}$ sequência Alfredo entra em casa e logo ouve, pela rádio, a notícia de que está sendo chamado na segunda-feira seguinte a comparecer à cooperativa para tratar assuntos de seu interesse. Fica ainda mais angustiado pois dá-se conta de que a transmissão pela rádio o coloca numa situação de constrangimento ante seus vizinhos; sente-se ainda mais humilhado, porque além de estar devendo uma quantidade exorbitante que sequer cabe em sua fraca matemática, ainda por cima ficará à mercê da chacota dos seus conhecidos. $\mathrm{Na}$ tarde do sábado, logo depois do almoço vai até o salão da comunidade onde tradicionalmente os moradores da localidade reúnem-se para jogar canastra. Em verdade, ele não quer jogar, 
porque sabe que não tem dinheiro, mas influenciado pelos companheiros acaba por jogar e nisso perde ainda mais do dinheiro que não tem.

- Senta aí, Alfredo. Chegou na horinha, íamos começar uma canastra.

Escusa-se.

- Que é isso? Nunca recusaste um joguinho. Vamos lá, senta aí.

Alfredo tem vergonha de confessar que está sem dinheiro. Se jogassem de graça, apenas para passar o tempo, aceitaria.

- É que esqueci a carteira em casa - murmura, quase inaudível.

- Não é motivo, toma aí - diz o amigo, estendendo-lhe uma nota de mil cruzeiros.

Apanha-a, titubeante (...) (KIEFER, 1994, p. 19).

$\mathrm{O}$ excerto em destaque revela que Alfredo sequer consegue se desvencilhar de participar do jogo de cartas proposto pelo amigo; provavelmente, em situações análogas, foi induzido a fazer outras coisas por não conseguir desprender-se em diálogos simples, por ser incapaz de formular respostas e argumentar em favor do que achava ser o certo a fazer. Novamente a ingenuidade de Alfredo é posta em voga, agora associada ao seu completo despreparo discursivo para manter-se firme em suas resoluções. Qualquer um fazia o que quisesse com o pobre agricultor que não dispunha de recursos cognitivos que permitissem defender-se de situações que envolvessem uma postura argumentativa. Isso fica claro logo adiante, quando o amigo indaga se ele ouviu o noticiário da COTRIPAU naquele dia, ao que ele responde asperamente que ouviu. Aspereza pode ser visto como o recurso mais fácil, aquele que ele tem à mão, porque não tem domínio nem de um possível discurso de proteção, nem de sua dívida, nem do jogo, nem de suas emoções, e isso se reflete em sua linguagem.

O protagonista de $O$ Pêndulo do Relógio lança mão então de um discurso de mentira, na tentativa de defesa. “- Deve ter saído o meu empréstimo - murmura, deixando a mentira transparecer no tom dúbio da voz (KIEFER, 1994, p. 20).” Como ele não é capaz de argumentar em sua defesa, resolve mentir para não se sentir diminuído ante aos demais, saindo logo em seguida em disparada em direção à latrina, por não ser capaz de sustentar o diálogo com os colegas e por pensar que os colegas sabem que ele deve ao banco.

Alfredo volta ao jogo e segue pensando em sua dívida e em como fará para pagá-la. Cogita brevemente pedir um empréstimo ao vizinho Herman Hauser, o mesmo que indagara se ele havia ouvido o noticiário, e com quem já disputara alguns palmos de terra na justiça e agora passava a duvidar das intenções do vizinho que buscava uma reaproximação.

Atrás daquele sorriso largo podem esconder-se intenções não tão honestas. Gato escaldado tem medo de água fria - pensa Alfredo. Escaldado, eis como 
se sente. Enganado iludido, incapaz de entender as transformações que vêm ocorrendo à sua volta. Tem a impressão de que alguma coisa está sendo destruída, lenta e irremediavelmente, dentro e fora de si (KIEFER, 1994, p. 24).

Depois de quinze anos tentando a produção da soja e de ter-se visto em situações vexatórias por várias vezes, Alfredo como que parece perder aos poucos a inocência, a ingenuidade. Passa a ficar sestroso, desconfiado. Suas reflexões permitem ver que está sendo enganado. No fundo ele até tem consciência de seus problemas, mas não consegue encontrar maneira de sair daquele problema, e a canastra o afunda ainda mais em dívidas.

A canastra pode ser uma alegoria da própria condição de vida, pois assim como provavelmente ocorreu com a produção agrícola, também iniciou o jogo influenciado pelos outros, e também como no jogo perdeu porque não compreendeu a dinâmica das jogadas; por fim, ambas acabaram por prejudicá-lo financeiramente.

Outra alegoria bastante importante existente na narrativa é a criada a partir da imagem de um porco, criada durante os acontecimentos na noite do sábado. Já em casa, bêbado e enfrentando a hostilização da família, Alfredo sente-se incomodado com o constante som do tic-tac do relógio, que embora presente na casa há vinte e sete anos só recentemente passara a causar-lhe incômodo. Em virtude disso, resolve dormir no paiol, e vencido pelo cansaço acaba por dormir. Durante o sono tem um pesadelo

Nele, está andando "pelas ruas da Cidade Desconhecida em completo desespero", onde riem e assobiam para ele, mas não consegue localizar a origem desses sons. Alfredo está sendo perseguido por um "animal espantoso" e foge dele, corre e por isso, "a chacota aumenta"; ouve "esgares de gozo e escárnio". Seus pés começam a afundar num lamaçal fétido e sente que o animal, que o persegue, está mais próximo. Em seguida, está boiando "num líquido quente" e percebe que, na verdade, "ainda é um feto, massa disforme. Luz, há luz no final do túnel”. Porém, logo, sente uma pressão intensa que "empurra para fora do útero" (SCALABRIN, 2011, p. 37).

Na sequência, "sons metálicos, rascantes, rasgam seus tímpanos (KIEFER, 1994, p. 33)" e Alfredo grita ao deparar-se, ao olhar-se na vitrine, não com um recém-nascido, mas com um porco. A Cidade Desconhecida pode facilmente fazer analogia à situação em que se encontra, da qual não consegue sair, é desconhecida porque ele não a domina, não tem controle sobre sua situação. Assim como no pesadelo ele foge da perseguição, na vida real do personagem ele foge de quem tenta aturdi-lo com o assunto, seja fugir da segunda-feira iminente, seja dos amigos durante o jogo. Como na vida, durante o sono não consegue emitir palavras, só se manifesta no grito de desespero ao ver-se transfigurado no animal que 
alimentara na primeira hora da manhã anterior e que mataria dali a algumas horas na tentativa de passar o tempo e dar uma alegria à família. Ao afiar a faca imagina-se matando alguns membros da cooperativa, mas logo arrepende-se, como se arrependerá também de matar a porca; "o urro do animal comove-o, retira a faca, arrependido, mas é tarde (KIEFER, 1994, p. 35)". Em verdade, Alfredo não se difere muito da porca; assim como ela, ele também apenas grita no sonhos, e seu grito é ruído, não é linguagem. Nesse ponto, torna-se importante o pensamento de Foucault, segundo o qual

O urro do primitivo que se debate só se torna palavra verdadeira se não for mais a expressão lateral de seu sofrimento e se valer por um juízo ou uma declaração do tipo: "eu sufoco". O que erige a palavra como palavra e a ergue acima dos gritos e dos ruídos é a proposição nela oculta. Se o selvagem de Aveyron não chegou a falar é porque as palavras permaneceram para ele como as marcas sonoras das coisas e das impressões que elas causavam em seu espírito; não haviam recebido valor de proposição (FOUCAULT, 2007, p. 129).

A própria inconsistência dos argumentos que Alfredo tentará usar no banco faz com que eles quase nada signifiquem, pois não se aplicam à lógica do banco; sua parca linguagem simples de nada servirão em sua defesa no banco. Mesmo assim ele tenta formular argumentos. Enquanto prepara o espaço para matar a porca, Alfredo "lembra-se que a

manhã terá de ir à Cooperativa enfrentar o monstro. Interrompe a faina para pensar melhor. Formula mentalmente as justificativas que apresentará (KIEFER, 1994, p. 37)”. Ele considera o evento do dia seguinte um monstro porque já supõe que não vai conseguir se desvencilhar daquilo; por não dominar, será mais uma vez dominado, então rumina tentativas de criar argumentos convincentes, o que ele também, no fundo, sabe ser incapaz.

Chegada a segunda-feira, dia de ir à cooperativa, Alfredo toma o ônibus e se reúne com outros agricultores em frente ao escritório. Ao aproximar-se um deles questiona

- Também foi chamado?

- Fui - responde, meio a contragosto.

O outro parece compreender o seu desejo de manter-se isolado. Afasta-se, murmurando qualquer coisa. Alfredo alivia-se, não terá de dar explicações. Prefere ficar em silêncio, ruminando. Sente-se mal na presença de pessoas muito falantes. O pai chamava-o moleirão. Injustiça do velho. Quando precisava dar duro, era o primeiro. Não, moleirão não era. Talvez tímido, retraído (KIEFER, 1992, p. 49).

Novamente a questão da linguagem é levantada dentro da narrativa. O protagonista era retraído, e também não gostava que outras pessoas falassem demais. Talvez ele não se sentisse 
confortável na presença de pessoas que tinham facilidade em comunicação, coisa que ele, definitivamente, não tinha. Ao ser chamado pelo funcionário da cooperativa que explicaria a real situação do agricultor este lhe informa que "seu problema é sério (p. 50)" e que "o banco está exigindo pagamento imediato (p. 50)". A sequência do diálogo é bastante representativa do que se pretende evidenciar, pois revela não só a dificuldade argumentativa de Alfredo, como também sua completa ingenuidade ante as regras do banco.

- De que jeito? Só se vendesse a terra.

- Impossível.

- Como impossível? Faço da minha terra o que bem quiser.

- O senhor não pode vender a sua propriedade.

- Posso saber por que não?

- O banco vai executar a hipoteca.

Hipoteca? Que hipoteca? Que história é essa? (KIEFER,1992, p. 51).

O funcionário explicou como funcionava a hipoteca e ressaltou que Alfredo havia assinado o contrato. Depois de refletir que mesmo trabalhando de sol a sol, quem ficaria com sua terra era o banco, enquanto ele seria tirado dela como uma planta invasora ${ }^{2}$.

- Não posso sair da terra. Como é que vou alimentar os meus filhos? Preciso dela para viver, não sei fazer outra coisa (...).

- Seu Alfredo, o senhor precisa entender. A culpa não é nossa, é do banco. Não podemos fazer mais nada. A última vez que o senhor esteve aqui, lembra? eu o alertei. agora é tarde (KIEFER, 1992, p. 51).

Ou seja, ao assumir a dívida, ele não ponderou os riscos financeiros e de segurança da propriedade que isso implicaria, e também, desconfiado que era, não levou em consideração o alerta do funcionário. A dificuldade de manter uma comunicação positiva, a falta de conhecimento da arquitetura da nova forma de cultivo agrícola, a incapacidade de ponderar opiniões de pessoas que possuíam um conhecimento diferente do seu, tudo isso levou Alfredo àquela situação.

Depois da conversa com o funcionário da cooperativa, o agricultor dirige-se ao banco, onde chama pelo funcionário e este sequer responde. Levanta a voz ao ponto de quase gritar para ser ouvido, desperta atenção de outros clientes e então "explica-se, engasgando-se,

\footnotetext{
${ }^{2}$ Scalabrini (2011) esclarece que em 1980, no presente da narrativa, a história seria verossímil, mas que poucos anos depois isso não faria mais sentido, pois, segundo ele "a Constituição Federal dispõe que 'a pequena propriedade rural, assim definida em lei, desde que trabalhada pela família, não será objeto de penhora para pagamento de débitos decorrentes de sua atividade produtiva (...)' (art. $5^{\circ}, \mathrm{XXVI)}$. Ocorre que esta proteção especial só the foi concedida a partir de 1988, depois do êxodo rural de aproximadamente 27 milhões de pessoas (p. 38)".
} 
atropelando-se nas palavras, o que o trouxe ali (KIEFER, 1992, p. 53)". Pouco tempo depois o funcionário volta dizendo ao agricultor que ele só poderá ser atendido na parte da tarde. Novamente evidencia-se a pouca intimidade de Alfredo com as palavras, especialmente em um lugar que não é natural para ele.

\begin{abstract}
Alfredo volta ao banco, espera, pede para ser atendido e ao saber que o gerente só poderá recebê-lo no dia seguinte

Possesso, Alfredo salta por sobre o balcão e avança em direção à sala do poderoso homem. Os funcionários chamam os vigias. Está explicando a situação ao assustado gerente quando os guardas entram. O homem ordena que esperem do lado de fora, a situação está sob seu controle.

O gerente promete dedicar especial atenção ao caso de Alfredo. Porém, antes de estender a mão, despedindo-se, sugere-lhe que vá procurando emprego, por segurança (KIEFER, 1994, p. 56).
\end{abstract}

O excerto em destaque pode ser representativo da relação de Alfredo com o contexto em que está inserido em virtude da linguagem, pois na falta de argumentos ele parte para a agressão. Seu interlocutor, o outro, não perde o controle da situação, mesmo estando prestes a sofrer uma agressão. É visível que os aspectos emocionais interferem grandemente nas ações do protagonista, o que agrava ainda mais sua situação perante os funcionários do banco e também dos outros clientes. Porém, o maior obstáculo que ele enfrenta é o linguístico, pois é incapaz de formular argumentos, de criar proposições firmes, de fundamentar suas justificativas em alegações convincentes que possam servir em seu socorro. E isso é o reflexo de outras situações em que foi ludibriado, em que desdenhou do conhecimento científico, em que se deixou levar por conversas; enfim, a condição em que se encontrava era o reflexo de suas decisões, as quais tomou muito em razão de seu insuficiente conhecimento dos mecanismos que envolviam a atividade agrícola que se propunha a fazer, relacionado a sua incapacidade de discernir o que era lucrativo ou não, o que seria ou não viável de fazer em sua propriedade.

Alfredo retorna para casa e tenta, pela primeira vez, contar à mulher o que aconteceu. Mente que teve apenas que assinar alguns papéis na cooperativa, mas ela percebe que não é verdade, então sugere que vão morar na cidade, depois de relatar que outro agricultor está em situação ainda pior que a deles por ter investido numa também fracassada produção leiteira. Alzira sequer cogita a possibilidade e ele então desiste de abrir-se com a esposa. Em "Alfredo emudece. Alzira tivesse dado chance, contaria a verdade. Mas ela não quer mesmo sair da colônia (KIEFER, 1994, p. 58)" é possível mais uma vez identificar que a relação com a linguagem, a inviabilidade de um diálogo franco tanto por parte de Alfredo que iniciou a 
conversa com mentira quanto de Alzira que sequer quis ouvir o que o marido teria a dizer foi determinante para a história, pois algumas horas mais tarde, tendo tentado na cooperativa, no banco e em casa solucionar o problema e não logrando êxito em nenhuma delas, o agricultor, a exemplo de tantos outros em situação semelhante na época em que a história acontece, acaba por enforcar-se no galpão da propriedade.

A imagem pendular do enforcado remete ao relógio que havia dentro da casa de Alfredo, cujo som passara a incomodá-lo nos últimos dias, mas também remete à obsolescência do homem do campo, que seria trocado pelas máquinas, como o relógio digital ocuparia o lugar do pendular. Nas palavras de Kiefer

\begin{abstract}
As camadas alegóricas ali são as seguintes: assim como o pêndulo parando representa a chegada do relógio digital, a morte do Alfredo representa a parada na história do Rio Grande do Sul daquele modelo patriarcal, agrário, minifundiário representado pela enxada e pelo ancinho. Está chegando a modernização da agricultura. E em outro nível ele também alegoriza a ideia de que para que o desenvolvimento econômico do campo venha, é preciso acabar com os "Alfredos Müllers". Porque o minifúndio atravanca a expansão do agrobusiness. Essa pequena terra tem de ser entregue para o banco, que vai vender em leilão para um grande proprietário de terras, e aquelas terras vão ficar de extensão para que a maquinização possa operar (KIEFER, s.n. 2013).
\end{abstract}

Interessante é que já havia relógio digital no banco em que Alfredo fora pela manhã e ele havia percebido que aquele não fazia barulho. por várias vezes o personagem relata o incômodo que lhe causava o tiquetaquear do relógio em sua casa, e ele até havia pensado em pará-lo, mas se compadeceu da esposa, que por vinte e sete anos havia dado corda ao relógio sem nunca deixá-lo parar. No entanto, no exato momento em que o agricultor comete suicídio,

na sala, depois de vinte e sete anos, o pêndulo do velho relógio diminui paulatinamente a distância entre um movimento e outro. Balança ainda no vazio, livre das engrenagens que determinaram seu curso por tanto tempo e, enfim, encontra o repouso absoluto (KIEFER, 1994, p. 60).

Tanto o relógio quanto o agricultor ficaram livres das engrenagens que o prenderam por uma vida toda. Nada mais havia a ser dito.

\title{
CONSIDERAÇÕES FINAIS
}

O Pêndulo do Relógio, como as demais obras de Kiefer de sua primeira fase, tem um apelo social bastante forte, pautada em preceitos do realismo, que tornam o texto bastante 
representativo de seu tempo e de seu lugar, embora continuem sendo ficção. Dada à grande similitude entre os textos e o contexto, a fortuna crítica de Kiefer baseia-se, principalmente na análise de aspectos sociais, na formação de pequenas comunidades do Alto Uruguai do Rio Grande do Sul, o êxodo rural, enfim. Alfredo Muller pode ser comparado a um grande número de agricultores que, assim como ele, foram vítimas do capitalismo, da chamada Revolução Verde, e acabaram perdendo suas terras ou até a vida em nome da grande produção agrícola. A falta de capacidade de análise, seu conhecimento restrito e linguagem idem aproximam-se dos pressupostos de Foucault (2007) quando diz que

Em sua forma mais geral, conhecer e falar consistem primeiramente em analisar a simultaneidade da representação, em distinguir-lhe os elementos, em estabelecer as relações que os combinam, as sucessões possíveis segundo as quais podemos desenvolvê-los (...) (FOUCAULT, 2007, p. 120).

Restrições na capacidade de analisar as representações circundantes, especialmente por meio do discurso de outrem, foram determinantes para o desfecho da vida da família de Alfredo. O protagonista da novela de Kiefer não dispunha de formação linguística suficiente para compreender todas as informações burocráticas e específicas referentes ao cultivo da planta que era novidade na época, menor ainda era a capacidade de entendimento dos termos do discurso de banco, conhecimentos jurídicos mínimos para avaliar contratos, juros e hipotecas, o que o colocou na linha de frente de um projeto que acabou dando errado. Não tinha preparo técnico para cultivar a soja, nem era adepto de seguir conselhos de quem entendia. Alfredo foi vítima de todo um sistema capitalista, e foi um alvo fácil de financiadores, pois não conseguia sequer compreender a dinâmica do meio em que estava inserido e menos ainda seria capaz de encontrar uma maneira de sair daquela situação.

\section{REFERÊNCIAS}

BAUDRILLARD, Jean. Simulacros e Simulações. Editora Galilée, 1981.

BENJAMIN, Walter, Magia e técnica, arte e política: ensaios sobre literatura e história da cultura. São Paulo: Brasiliense, 1994.

CULLER, Jonathan, Teoria Literária: uma introdução. São Paulo. Beca Produções Culturais LTDA. 1999.

EAGLETON, Terry. Teoria da Literatura: uma introdução. Martin Fontes, 2006

FOUCAULT, Michel. As palavras e as coisas: uma arqueologia das ciências humanas. São 
Paulo: Martins Fontes. 2007.

KIEFER, Charles. Charles Kiefer discute sua obra e fala sobre o porquê de ter assumido a função de retratar o minifúndio alemão no RS. [Entrevista disponibilizada em 24/04/2013]. Disponível em: https://gauchazh.clicrbs.com.br/cultura-e-lazer/noticia/2013/05/charles-kieferdiscute-sua-obra-e-fala-sobre-o-porque-de-ter-assumido-a-funcao-de-retratar-o-minifundioalemao-no-rs-4148409.html.

Entrevista concedida a Fernando Gomes. Acesso em: 14/10/2019

KIEFER, O Pêndulo do Relógio. 6. ed. Porto Alegre: Mercado Aberto, 1994.

SCALABRIN, Leandro Gaspar. Os desgarrados do campo: texto e contexto na obra de Charles Kiefer. 2011.

Disponível

em:

http://tede.upf.br/jspui/bitstream/tede/933/1/2011LeandroGasparScalabrin.pdf. Acesso em $\underline{14 / 10 / 2019}$. 